\title{
INTERNATIONAL NORMS AND HUMAN RIGHTS CONDITIONS IN THE XINJIANG UYGHUR AUTONOMOUS REGION (XUAR)
}

\author{
Roy Anthony Rogers and Jatswan S. Sidhu
}

\section{ABSTRACT}

The Uyghurs are a Muslim minority living in Xinjiang, northwest of China. The area came under Chinese control in the mid-18th century and since then these people have encountered cultural and religious persecutions under Chinese rule, especially prior to the 1980s. Nonetheless, the reforms initiated by Deng Xiaoping in the 1980s have contributed to economic and social development in Xinjiang, at the very least. As a result, the Muslim Uyghurs were allowed to perform their religious obligations and practice their culture. Although there was been an overall improvement in human rights conditions in Xinjiang, however, these reforms have also resulted in an influx of Han Chinese into the province, thus resulting in the rise of tensions over cultural and religious differences between the two groups. This in turn has contributed to ethnic unrest in Xinjiang with Beijing reverting to its harsh policies of the past. In the light of these developments, the Uyghur diaspora community has made attempts to internationalise the plight of Xinjiang's Muslim Uyghurs. This article examines the reactions of transnational advocacy networks (TANs), like-minded states, and international organisations to human rights conditions in Xinjiang as well as the responses of the Chinese government to pressures from both external and internal actors. In doing so, this article has adopted the five phase spiral model to analyse the changes in human rights conditions in Xinjiang.

Keywords: Uyghur, human rights, international norms, Xinjiang, China, spiral model.

\section{INTRODUCTION}

Human rights are rights attached to all human beings by virtue of them being human and due to their nationality, membership of a particular 
social group or status. ${ }^{1}$ International awareness on human rights developed as a result of the mass atrocities committed by belligerent states during World War I and World War II. As a result, world leaders began addressing the issue of how states should treat their people thus making it a legitimate concern of the international community, especially in cases of genocides. As a result, the United Nations (UN) Charter put in place Articles 55 and 56 that obligates member states to observe and promote human rights and fundamental freedoms. This was later incorporated into treaties and conventions such as the 1948 Universal Declaration of Human Rights (UDHR). ${ }^{2}$

"Norm" is a concept that has gained much attention from scholars of international relations. International norms are a set of rules that influences a state's behaviour. Norms also reflect the values that should be upheld by the international community, because norms specify those actions that are legitimate and those that are illegitimate. In addition, they specify the rewards for adherence and punishment for non-compliance to these values.

In 1949, the Chinese Communist Party (CCP) took control of Xinjiang from the Kuomintang (KMT) and in 1955 declared it as an autonomous region. Despite its autonomous status, major decisions were however still made by the CCP, predominantly comprised of Han Chinese and with little representation of the Xinjiang Uyghurs.

Ethnically, Xinjiang's population can be divided into two major groups: the indigenous Turkics and the non-Turkics. The Turkics are further divided into the Uyghurs, Kazakhs, Kirghizs, Uzbeks and Tajiks, the majority of whom are Muslims. However, the Uyghurs are not confined to Xinjiang alone as they are also found throughout the region, namely in Afghanistan, Uzbekistan, Kazakhstan, Turkmenistan and parts of Russia. The non-Uyghur group comprise of the Han Chinese, Hui, Mongolian, Dolan, Loplik, Abdal, Salar, Dongxiang, Zhung, Tibetan, Taranchi, Sibo, Solon, Bonan, Manchurian and Russian people. ${ }^{3}$ The large number of nationalities in the province is due to the migration from China proper since the late 1950s. Demographically, the Chinese Hans are mainly concentrated in Xinjiang's northern and eastern parts. According to the 2000 Census of China, the total population of Xinjiang was $18,459,511$. Of this, 
the Uyghurs comprised 45.5 percent, the Hans 40.6 percent and the Kazakhs 6.7 percent. $^{4}$

This article examines the reactions of TANs, like-minded states, and international organisations to human rights violations in Xinjiang. The article also discusses the responses of the Chinese government to pressure from both external and internal actors. This article has adopted the five phase spiral model to analyse the changes in human rights conditions in Xinjiang from 1992 to 2009. The spiral model is crucial to this study because it provides an explanation of the phases a state goes through, and indicates whether human rights conditions have improved or otherwise due to pressure from the within and without. Most previous works on the subject ${ }^{5}$ offer little theoretical analysis on how China has reacted to pressure from within and without.

The article begins by introducing the five phase spiral model and then explores the years of repression under the Mao Zedong administration, especially during the Cultural Revolution between 1966 until 1977. It is important to note that political activity in Xinjiang during this period remained dormant, such that there was no or little opposition to Chinese rule from the indigenes. Moreover, the Sino-Soviet split in the 1960s forced China to adopt an isolationist policy thus insulating itself from the rest of the world. As a result, Xinjiang remained isolated and Chinese human rights abuses in the province simply failed to receive any attention from the international community.

\section{THE FIVE-PHASE SPIRAL MODEL}

The five phase spiral model of human rights change was developed by Risse and Sikkink ${ }^{6}$ and is organized into five phases/stages. It attempts to analyse the variations in the way a target state moves towards the improvement of human rights conditions in the country. It identifies the conditions under which a state moves from one phase to the next. These phases are distinguished by the dominant response of the target state to pressure from within and without.

The first phase of the model is repression, which occurs when the domestic opposition in the target state is too weak to challenge the government. Hence, it organises 'boomerang throws' with the 
main objective of externalizing the issue and gaining the attention of the international community. The boomerang throws are aimed at providing the necessary information pertaining to repression and human rights violations committed by the state to the TANs. The objective is to expose the norm-violating state and appeal to the international community for a reaction. All the same, these boomerang throws can also be aimed at like-minded states for failing to respond to human rights violations. The objective is to pressure the international community to respond critically to the norm violating. Moreover, the model also allows for anticipation of the future direction of the target state in dealing with issues related to international human rights norms. The duration of phase one varies from one state to the other as in some cases repression may last for a long time and international reaction might not be forthcoming. The initial activation of the human rights network can be due to various human rights violations against the domestic opposition such as arbitrary arrests, torture and even execution of political detainees. When these tragedies are externalized, this leads to the mobilization of the international human rights network. The TANs and like-minded states will then lobby in order to persuade the target state to stop the violations and eventually improve human rights conditions.

In second phase known as denial, the target state, when cornered over its poor human rights record, simply rejects these allegations and may even mobilise nationalistic sentiment against foreign criticism. If faced with an insurgency, it will manipulate the situation by promoting the view that it is safeguarding national security and also by using fear to justify its policies. Hence, any domestic challenge will be considered as disloyal and thus a threat to the state. It is noteworthy to mention that the second phase poses one of the greatest challenges to the TANs particularly when it comes to pushing the target state to the third phase. It very much depends on the strategies adopted by the TANs as well as the vulnerability of the latter to pressure from without. Success in this phase is measured by the target state's acknowledgement of its poor human rights record and its willingness, albeit in a limited manner, to do something about it. ${ }^{7}$

The third phase, known as tactical concessions, unfolds when international pressure continues and ultimately prevails. The normviolating state will then adopt some minor changes, such as the 
release of political detainees, mainly aimed at defusing the situation and warding-off criticism from without. The purpose of granting these concessions is a tactical and highly manipulative move, mainly aimed at regaining legitimacy, international assistance and/or defusing international criticism. The third phase is highly crucial, as these concessions in turn enable the domestic opposition to reorganize and gain some lost ground. Therefore, if the target state continues to violate human rights, it may have to encounter pressure from within as well as from the international community. Nonetheless, there is always a possibility of a backlash with the target state reverting back to repression. Once the third phase prevails, the target state may move to the fourth phase known as prescriptive status. Here, it may ratify and internalize international human rights conventions and norms with some marked improvement in its human rights record. All the same, pressure from both within and without must continue as the absence of it may allow for regression with the target state moving backwards.

The fifth and final phase is of the spiral model is known as rule consistent behaviour. According to Risse and Sikkink, the fifth phase involves international human rights norms being fully institutionalised domestically and then internalised. ${ }^{8}$ This means that they are implemented and enforced, with domestic laws are promulgated in accordance with international human rights norms. At this phase, there are clear mechanisms within the target state to provide checks and balances over the power of the government. However, it is interesting to note that not all states experience a positive flow or forward wave from the first phase until the final phase. Human rights conditions in a target state may stagnate at a certain phase (especially at phases two and three) and not move forward. A state may even encounter a reverse wave, which occurs when its government decides to re-introduce harsh and repressive laws in the name of national security.

\section{XINJIANG: DECADES OF REPRESSION}

The first phase began upon China annexing the province in 1949. Aimed at appeasing the non-Han people, in October 1955, the CCP established the Xinjiang Uyghur Autonomous Region (XUAR or Xinjiang Weiwuer zizhiqu).9 The establishment of the XUAR gave the non-Hans the opportunity to govern at the lower levels of the administration in positions such as chairman of county, district or 
prefecture. This was part of the appeasement policy adopted by the CCP to obtain support from the local Uyghur leaders. However, whereas the non-Hans held the local chairmanship positions, the Hans held the vice-chairmanship positions. ${ }^{10}$ In addition, key positions in the provincial administration such as First Field Army Commander and First Secretary of the Xinjiang Communist Party (XCP) were held by Hans. Although the post of Chairman of the XUAR People's Council was held by Saifuddin, a non-Han, the executive power actually rested in the hands of Wang Enmao, the First Secretary and also a Han. Moreover, each autonomous unit was placed under the direct control of the XCP, which was led by the Hans. The XCP itself was under the Northwestern Bureau in Xi'an, which was answerable directly to the Central Party office in Beijing. ${ }^{11}$ Although Xinjiang had been granted the status of autonomous region, the actual administrative power of the province remained in the hands of Beijing. However, this was short-lived because in the 1960s and aimed at tightening its grip on the province, Beijing and unleashed a series of repressive policies geared at silencing all forms of dissent.

Beginning in the $1960 \mathrm{~s}$, the CCP started introducing repressive policies, instead of the more accommodative ones earlier. The CCP was suspicious of Islam and Uyghur traditions, which they considered as feudalistic and anti-revolutionary. Hence, they were convinced that the influence of Islam and Uyghur traditions should be wiped out through the implementation of harsh policies.

During the Great Leap Forward (1958-1961), the conditions in Xinjiang worsened. The province suffered from starvation due to food shortages. Ironically, despite the acute shortage of grain, Xinjiang was forced to export about 30,000 tons of grain to other Chinese provinces between 1960 and 1962. ${ }^{12}$ The Hans, predominantly in the north of Xinjiang, received shipments from the Uyghur south. As a result, the worst affected areas due to food shortages during the Great Leap Forward years were Kashgar, Kucha, Yili, Tacheng and Aqsu that were mainly inhibited by the Uyghurs. At least 1,000 people starved to death in these areas. ${ }^{13}$ In fact, even in the provincial capital, Urumqi, people had to endure starvation and that was eventually relieved by shipments of grain amounting to 4,400 truckloads. ${ }^{14}$ However, these additional supplies of grain were basically intended to relieve the Hans, stranded in the city. The non-Hans were left to find their own 
food. It is believed that some people in Urumqi were at times even compelled to eat tree bark. Hence, between April and May 1962, at least 60,000 non-Hans fled from the Yili and Tacheng districts to the Soviet Union. ${ }^{15}$ This made the CCP even more suspicious of the nonHans, whom they regarded as being disloyal and ungrateful.

Following the failure of the Great Leap Forward and criticism of the Hundred Flowers Movement in 1965, Mao Zedong wanted to reconsolidate his position in the CCP. He blamed the failure of the Great Leap Forward on party leaders who were liberal minded. In the following year, Mao Zedong launched the Great Proletarian Cultural Revolution which was a political campaign intended to purge all those considered to be liberals.

In Xinjiang, the situation was no better than in other provinces. Once the Red Guards from Beijing arrived in Xinjiang in 1966, they started to persecute local leaders, including Uyghur political leaders such as Burhan, the former Governor of Xinjiang, and Iminov, the ViceChairman of XUAR, who were stripped of all their official positions. They were accused of treason and purged. There were also reports that several Uyghur leaders had been arrested and executed; among them were Anwar Saljan, Iminov and Askhat Iskhak, who were once members of the Eastern Turkestan Revolution (ETR) in the 1930s. ${ }^{16}$

During the Cultural Revolution, the Red Guards opposed the policies of accommodation and local autonomy and as such many Uyghurs were deprived of their jobs in the government. In 1962, there were 111,500 Uyghurs working for the provincial government holding various posts such as clerks, policemen and district and county chairmen. However, by 1975, there were only 80,000 non-Hans left working for the government. ${ }^{17}$

In addition, the Uyghurs also encountered religious and cultural persecution. All Uyghur traditional dance and music was strictly prohibited, and these even included engagement and marriage ceremonies as well as circumcision rituals. The Uyghurs were not even allowed to be in possession of their traditional musical instruments. Conditions became even worse during the reign of the Gang of Four. Mao's wife, Jiang Qing, who was one of its members, openly expressed her hatred towards Xinjiang and the Uyghurs. She was quoted as saying "what is special about your tiny Xinjiang? I despise you."18 She even 
called these minorities, including the Uyghurs, "foreign invaders and aliens." 19

In addition, anti-Islamic and anti-Uyghur propaganda intensified during the Cultural Revolution. ${ }^{20}$ According to one of the Uyghurs who lived in Yengisar county, located not far from Kashgar, in 1971 "several white and black pigs were kept in a building people called 'mosque'. There was a small window on the wall. I was too short to be able to see the pigs from the window, so my elder sister put me on her shoulder. When I grew older I found out that almost all the mosques in our region were turned into pig houses. Even Uyghur songs were written in praise of pigs". ${ }^{21}$

The demise of Mao Zedong and the failure of the Gang of Four to seize power in 1976, eventually brought Deng Xiaoping to the helms of power. In 1978, Deng was installed as Chairman of the CCP during the Third Plenum of the Eleventh Central Committee held in Beijing, which gave him full control of the administration of China. Henceforth, he introduced reform policies which emphasised on political stability through economic development rather than through ideological means.

Economic development in minority areas such as Xinjiang, Tibet, Kansu, Qinghai and Ningxia, thus became a major concern of the CCP. As Beijing wanted greater participation of the Uyghurs in government, therefore the 1984 Law on Regional Autonomy for National Minorities created a quota system for minority participation in the state's administration. By the mid-1980s, the CCP had initiated an affirmative action policy intended to place more minority cadres in the party and government. The CCP's provincial began to emphasize on the education and training of Uyghur cadres, especially in the area of technical and skilled work. With this liberalisation, the Uyghurs and other Turkics were allowed to wear their native costume, thus replacing Mao suits.

It is essential to note that the economic reforms initiated by Deng Xiaoping did improve human rights conditions in Xinjiang. However, it also created new tensions and dilemmas for the CCP. Although Deng Xiaoping initiated economic reforms, he was still conservative in relation to liberalising the Chinese political system, unlike reformists such as $\mathrm{Hu}$ Yaobang and Zhao Ziyang, who were very supportive of political liberalisation. 
The rapid economic development in Xinjiang during the 1990s contributed to the increase of Han migrants into the province. Related to this, Jiang Zemin was quoted as saying, "Bu dao Xinjiang, bu hao Han" or "if you haven't been to Xinjiang, you're not a good Han!" As a result, more incentives were offered to encourage 'hao Hans' or 'good Hans' from Central China to migrate to Xinjiang, with the justification that this would 'develop the West.' ${ }^{22}$

In addition, $\mathrm{Hu}$ Yaobang, the former CCP Secretary General, was quoted as saying that the future of China lay in its western provinces where up to two hundred million Han Chinese could be relocated to become the moving force for economic modernisation. ${ }^{23}$ If this were to happen, the Uyghurs, who were subjected to a birth control policy, would have become a minority in their own province. Despite the call by Tomur Dawarnet, the Uyghur Chairman of the Regional Government, to control the migration of Hans into the province, the policy literally remained unchanged.

Aimed at controlling Xinjiang's Uyghur population, Beijing initiated a birth control policy. The policy allowed Uyghur couples to only have three children in the rural areas and two in the urban centers. However, according to a report by Amnesty International in April 1999, the authorities exerted pressure on couples to reduce the number to two in the rural areas and one in urban centers as well.

In addition, couples had to apply to have a child ${ }^{24}$, or in other words, pregnancies had to be planned according to the quota for permitted births allocated to a particular area over a given period. There were cases where couples had to wait for a number of years before being granted permission to have a child. If a woman became pregnant before obtaining permission, she could be forced to abort the child, although the practice is clearly prohibited in Islam. Noncompliance could result in the denial of medical and health benefits as well as salary cuts. ${ }^{25}$ On the said policy, an Uyghur who worked for the health department in East Turkestan remarked that "if our children are limited, we will disappear." 26 While the one child policy was practised almost throughout China, in Xinjiang, Han migrants were permitted to have two children. This was in fact considered an incentive for Hans to migrate to Xinjiang. Forced sterilisation of non-Hans was also reported to be a common practice in the province. 
Although Xinjiang experienced rapid economic development in the 1990s, it appeared to benefit only than Han migrants more than the locals. In addition, administrative power in the province was in the hands of the Hans. By 1992, Wang Enmao, who was a pragmatic leader, retired and was replaced by Wang Lequan, a hardliner. Under Wang Lequan's leadership, any Uyghur who criticised the government faced persecution and crackdowns intensified on Uyghurs who publicly embraced their cultural identity.

In education, many new restrictions were imposed on the Uyghurs. Beijing banned the historical works of Turghun Almas, who claimed that the Uyghur civilisation had predated the Han dynasty, thus contradicting official Chinese historical interpretations which claimed that Xinjiang had always been part of China. ${ }^{27}$ According to Southerland ${ }^{28}$, textbooks were rewritten so that the Uyghurs would not be able recognise their own history. In fact, compared to Chinese schools, many Uyghur schools in Xinjiang were so poorly equipped and deprived of basic facilities such that the students had to sit and write on the floor. On the contrary, students in Chinese schools had a better chance to further their studies and to seek professional careers in Xinjiang or elsewhere in China. ${ }^{29}$

Although statistics published by the CCP indicate that the province experienced rapid economic development in the 1990s, unemployment was high among the Uyghurs. Hans were concentrated in the modern cities of northern and north eastern Xinjiang, including Urumqi, while the Uyghurs occupied the south. The Uyghurs complained that racial abuse and discrimination against ethnic minorities had become a common problem and that there were no equal opportunities for employment.

Apart from racial discrimination, the social and cultural rights of the Uyghurs were also curtailed. For example, social and cultural forums known as the meshrep were revived in 1994 but banned a year later. Beijing was worried that the Uyghurs might use the meshrep to promote Uyghur solidarity. In addition, Uyghur leaders who publicly promoted Uyghur culture and traditions were blacklisted by the government and they and their family members suffered harassment. ${ }^{30}$ Many Uyghurs viewed Xinjiang not as an autonomous region but a "Chinese colony" that was a victim of "Sinification". 
Harsh policies were implemented to overcome resistance from the Uyghurs, which instead only increased the anger and hatred between these two communities. The Uyghurs responded in a variety of ways, one of which was public protest. The Chinese administration in Xinjiang encountered several major demonstrations, such as the Baren (Kashgar) incident in April 1990, the 1995 Ili demonstrations and the 1997 Yining demonstrations. All of these demonstrations were suppressed by the People's Liberation Army (PLA), and crackdowns intensified.

In March 1996, the CCP Central Committee drafted a document known as Document No. 7. It comprised a set of recommendations on ways to overcome 'separatism' and 'illegal religious activities' in Xinjiang. The document also emphasised the relevance of transporting Hans to Xinjiang to occupy important positions and expressed the CCP's apprehension about granting the Uyghurs various social and cultural rights.

Subsequently, in April 1996, the Standing Committee of the Political Bureau held a meeting chaired by President Jiang Zemin to discuss the security problems in Xinjiang. After the meeting, the Chinese government issued a classified document known as 'Strike Hard' or yanda ${ }^{31}$ that was indicative of how the Beijing leadership dealt with the challenges confronting Chinese rule in Xinjiang. ${ }^{32}$

The Chinese government responded by blaming the series of unrest in the 1990s on what it considered the 'Three Evils', namely 'religious extremists,' 'terrorists' and 'separatists.' Therefore, in mid1996, it launched a campaign against the so-called 'three evils' which saw increased arbitrary arrests and imposition of further restrictions on the cultural and religious rights of the Uyghurs. As the human rights situation sharply deteriorated in Xinjiang and with little or no domestic opposition at all, the Uyghur diaspora abroad began organising a series of activities aimed at internalizing the issue. Thus began the activation of network that will be discussed as follows.

\section{THE ACTIVATION OF NETWORK AND THE INTERNATIONALIZATION OF THE XINJIANG ISSUE}

While the issue of Chinese repression has been evident in Xinjiang since 1949, its internationalization only began in the 1990s namely due 
to at least two reasons. The first relates to the outbreak of violence in the province and the second is related to increased repression by the Chinese. On this, the issue of 'world time' argued Risse and Sikkink must be highlighted. On this, the authors argue that it was not until the end of the Cold War that human rights issue were internationalized. Moreover, the global human rights normative architecture was still evolving since the declaration of the UDHR in 1948. Additionally, while organizations such as AI had existed since 1960s, the focus of attention was Latin America where military coups had dealt a severe blow to democracy in many countries. ${ }^{33}$ In the case of China, as the country only began opening up to the world in the late 1980s, obtaining information on human rights violations thus became an uphill task, more so isolated provinces like Xinjiang. It was not until the 1989 Tiananmen massacre that human rights violations in China were internationalized. Thus, the end of the Cold War not only marked an end to ideological rivalry but even pushed human rights issues to the centrefold.

The outbreak of violence in Xinjiang and the human rights abuses in the 1990s led to the formation and mobilisation of an international network that was deeply concerned with the deteriorating situation in the province. The Uyghurs living in Xinjiang, with the support of the Uyghur diaspora, launched several boomerang throws. This brought about the development of international Xinjiang solidarity groups, thus moving the issue to a new phase of internationalisation. It not only involved non-governmental organisations, there was also pressure from a number of states to take a harder stance on China with regards to its human rights policies. Numerous reports and articles on the human rights situation in Xinjiang were also published via the internet. This created a 'virtual community' or network of people around the world who were concerned about the poor human rights conditions in Xinjiang.

This article has divided the Xinjiang human rights network into three major groups mainly consisting of international nongovernmental organisations (also comprising of human rights solidarity groups established by both the Uyghur diaspora and nonUyghurs), international organisations and states such as the United States and Turkey. These groups may differ in their approach but they have expressed deep concern about the sequence of serious human 
rights violations that have occurred in Xinjiang and are working to pressure China to improve its human rights policies.

\section{THE UYGHUR HUMAN RIGHTS NETWORKS}

One of the key solidarity Uyghur diasporic group is the Uyghur American Association (UAA), based in Washington DC and was founded in May 1998 at the First Uyghur American Congress. Since then, the UAA has organised several congresses to unify the Uyghur community living in the U.S. and to represent the collective voice of the Uyghurs. The UAA organises public lectures and forums to raise awareness regarding the plight of their people in Xinjiang and has held demonstrations in front of the Chinese Embassy in Washington D.C and during official visits of top Chinese leaders to the U.S. ${ }^{34}$

The UAA also gathers information and coordinates action, such as issuing magazines and weekly information via e-mails. They also maintain close contact with the American Congress and the U.S. State Department. In 2004, the UAA organised a symposium where young Uyghur professionals met with American Congressmen to voice the plight of their brethren in Xinjiang. ${ }^{35}$ The UAA was able to garner the support of the Congressmen to sponsor a bill calling on China to end repression of Tibetans and Uyghurs. ${ }^{36}$ During President Barrack Obama's visit to China in 2009, the UAA urged him to inform China of its social responsibilities to the Uyghurs and improve human rights conditions in Xinjiang. ${ }^{37}$

The UAA also works with international human rights groups such as Amnesty International (AI) and Human Rights Watch (HRW). It has undertaken the Uyghur Human Rights Project (UHRP) as part of its struggle to improve human rights conditions. The UAA has been linked with other Uyghur diaspora in the U.S., Europe, Turkey, Central Asia and Australia. The UAA has also helped to promote the Uyghur language, history, culture and heritage in the U.S. through conferences.

Another Uyghur diasporic solidarity group is the World Uyghur Congress (WUC). Established in April 2004 in Munich, its first president was Erkin Alptekin. Its aim is to raise awareness regarding human rights conditions in Xinjiang. It has hosted a range of speakers including Riza Bekin and Erkin Alptekin, who have accused the 
Chinese government of being a coloniser that destroys the culture of its people. The WUC has also called on the international community to pressure on China. It maintains its own websites and receives funding from the U.S.-based National Endowment for Democracy (NED). In 2008, the NED provided about USD 550,000 to the UAA and WUC. Like the UAA, the WUC has links with other Uyghur diaspora all over the world. Rebiya Kadeer has been its president of the WUC since 2006.

It should be mentioned that Rebiya Kadeer has also played an important role in internationalising the plight of the Uyghurs and in seeking international pressure on China. In July 2008, on the eve of the Beijing Olympics, Rebiya Kadeer met with President George W. Bush at the White House. ${ }^{38}$ President Bush expressed his grave concern for the Uyghurs' quest for human rights and said he would raise the human rights issue with Chinese leaders during his visit to Beijing. According to Rebiya Kadeer, "his decision to meet with us at this time will send a powerful message to the Chinese government that it does not have a free hand to commit human rights abuses." 39 In fact, she had previously met President Bush in Prague in June 2007, where he delivered a speech at a conference on democracy. During his speech, President Bush praised her as a defender of human rights.

Similarly, in November 2007, Rabiya Kadeer was invited by the US Congress to address the Congressional Human Rights Caucus (CHRC) regarding the problem of the trafficking of Uyghur women in Xinjiang. The CHRC was co-chaired by Congressman Tom Lantos and Congressman Frank R. Wolf. Rabiya Kadeer was able to convince the attention of several representatives who were present. Among them was Ambassador Mark P. Lagon, Director of the Office to Monitor and Combat Trafficking in Persons at the U.S. State Department. Representative Chris Smith of New Jersey was also critical of Chinese policies that sought to assimilate the Uyghurs by force. In 2007, Rebiya Kadeer, as president of WUC, was the recipient of the Congressional Gold Medal. This demonstrates that the WUC had been able to attract the attention of the U.S. law maker, at least to some extent. ${ }^{40}$

Apart from meeting leaders from the U.S., Rebiya Kadeer met Kofi Annan ${ }^{41}$ then Secretary General of the United Nations in September 2006 during United Nations Week at the UN headquarters 
in New York City. She wanted the UN to be aware of the plight of the Uyghurs and do something in order to influence China to improve the human rights conditions in Xinjiang. She also met with other leaders such as Vaclav Havel, former President of the Czech Republic, in February 2007. During her meeting with Havel, she thanked him for his efforts in the promotion of human rights and democracy, especially in voicing the plight of her people. ${ }^{42}$

Rebiya Kadeer made a similar appeal to Prime Minister Yukio Hatoyama and the Japanese government during her visit to Tokyo in October 2009. Despite China's strong condemnation, the Japanese government granted Rabiya Kadeer entry into Japan. However, the Japanese Foreign Minister, Katsuya Okada, assured the Chinese that no Japanese cabinet minister had met Rabiya. ${ }^{43}$ On 29 September 2010, Rebiya Kadeer and Alim Seytoff, the spokesperson of WUC, visited the U.S. Military Academy at West Point. Despite pressure from the Chinese government, the U.S. Military Academy proceeded with Rebiya Kadeer and Alim Seytoff's visit. They both spoke on human rights conditions in Xinjiang.

Rebiya has gained much admiration and respect not only among the Uyghurs but among non-Uyghur leaders as well. According to Linda Benson, a professor at Oakland University in Michigan who specialises in western China, the Uyghurs require a charismatic leader to voice their struggle at the international level, and Rebiya fulfils this role. Benson states that, "There's been a need for a long time for that movement (Uyghur) to have a major figure that they can call upon to represent them, she (Rebiya Kadeer) makes a great figurehead, because she's a woman, because she's Muslim, because she's outspoken and she's a mother." 44

The WUC has been actively involved in raising international awareness regarding the plight of the Uyghurs. It has participated in international forums and organised workshops and meeting media representatives from all over the world to explain the human rights conditions in Xinjiang. For example, on 27 September 2010, the WUC participated in a roundtable discussion on 'Digital Democracy Using Virtual Ways to Promote Real Rights' which was held in Geneva, and organised by the Nonviolent Radical Party, Transnational and Transparty (NRPTT) in collaboration with the Unrepresented Nations 
and Peace Organisation (UNPO), as a side event of the 15th Session of the UN Human Rights Council. During the roundtable discussion, Kathy Polias, the WUC's UN liaison officer, spoke on the ethnic unrest in Xinjiang and the state-imposed information blackout in the province in the aftermath of the July 2009 riots.

\section{INTERNATIONAL NONGOVERNMENTAL ORGANIZATIONS (INGOS)}

As far as INGOs are concerned, one key group is AI, which has been reporting on human rights violations against the Uyghur in Xinjiang. AI started to focus on human rights violations in Xinjiang following the suppression of an initially peaceful rally in Yining (Ghulja) in February 1997, which resulted in riots in the city and arbitrary arrests by Chinese authorities. The introduction of the 'Strike Hard' policy and the detention of Rebiya Kadeer in August 1999 also attracted the attention of $\mathrm{AI} .{ }^{45} \mathrm{AI}$ uses a range of methods, which include talking to the victims, liaising with human rights activists, monitoring international and Chinese media regarding the situation in Xinjiang, publishing detailed reports, informing the news media and publicising documents, leaflets, posters, advertisements, newsletters and websites.

In addition, AI also organises public rallies in front of Chinese embassies in major Western cities to protest against China's policies towards the Uyghurs. It also lobbies governments and international organisations such as the UN and EU, emails petitions and organises letter-writing campaigns to international leaders to intervene and pressure China, and targets appeals (most commonly for individual prisoners of conscience or political prisoners) as in the case of Rebiya Kadeer, which lasted from 1999 until her release in 2005. AI also works with other campaigning groups such as the UHRP, HRW, Unrepresented Nations and Peoples Organisation and the Minority Rights Group. AI has also sought cooperation from the Uyghur diaspora in organising a speaker's tour with Rebiya Kadeer.

One of the major concerns of the AI is the condition of Alim Abdulreyim, the son of Rebiya Kadeer. According to AI, Alim Abdiriyim has been subjected to torture and ill treatment while in detention. Hence, AI together with Rebiya Kadeer's family have urged the Chinese government to ensure that Alim Abdulreyim is not tortured 
or ill-treated in prison and is provided with the necessary medical treatment. In addition, AI has called on the Chinese government not to harass any of Rebiya Kadeer's family members.

Another non-Uyghur human rights solidarity group is Human Rights in China (HRIC). The HRIC was founded by Chinese students and scholars during the Tiananmen protest in 1989. The HRIC is based in New York with its regional in Hong Kong and receives funding from the NED. The objective of the HRIC is to promote international human rights norms in China. It works closely with the UN, World Trade Organisation (WTO) and the European Union (EU) by providing them with reports on human rights conditions in China.

The HRIC has often highlighted the plight of the Uyghurs and human rights conditions in Xinjiang through its publications. One of these publications is entitled Devastating Blows: Religious Repression of Uighurs in Xinjiang published in April 2005. ${ }^{46}$ The report was prepared jointly with HRW and focuses on China policies with respect to the Uyghurs. The report claims that the Uyghurs have been denied freedom of association, assembly and have not been allowed to express their religious beliefs freely. In April 2007, the HRIC also published a report entitled China: Minority Exclusion, Marginalization and Rising Tension, which was commissioned by Minority Rights Group International (MRGI). The report highlights the situation faced by ethnic minorities living in China in the areas of political participation, development and preservation of cultural identity. All these report published by the various organizations discussed above have to large extent enabled for the internationalization of the human rights conditions in Xinjiang and raised awareness on the issue.

\section{INTERNATIONAL ORGANISATIONS}

International organisations (IOs) have also expressed concern about the poor human rights conditions in Xinjiang have been calling on China to improve the situation. One of these is the Organisation of the Islamic Conference (OIC). The OIC has expressed its grave concern over the outbreaks of violence in Xinjiang since the 1990s, especially following the July 2009 riots, calling on China to investigate the reasons behind the outbreak of violence. In addition, it has on numerous occasions appealed to China to ensure that the Uyghurs are provided basic rights 
to maintain their religion and culture. In the aftermath of the July 2009 riots, the Secretary General of the OIC, Ekmeleddin Ihsanoglu, called on China to carry out effective and transparent investigations into the incident. He was quoted as saying that "the Islamic world is expecting from China, a major and responsible power in the world arena with historical friendly relations with the Muslim world, to deal with the problem of the Muslim minority in China in a broader perspective that tackles the root causes of the problem." ${ }^{47}$ Ekmeleddin Ihsanoglu also expressed his intentions to visit Xinjiang.

Meanwhile, in August 2009, the OIC sent a high-level delegation led by Ambassador Syed Qasim al-Masri, who was the Head of the Committee for Muslim Minority Affairs, to visit China as part of a fact-finding mission. During the meeting, Chinese officials explained their position on the treatment of the Muslim minorities, especially the Uyghurs, including the scope of authority of the Uyghur autonomous government, issues related to religious freedom and the various integration programmes implemented by China. It is interesting to note that during the meeting, Chinese officials reaffirmed the importance China attaches to the Muslim world and how it cherishes its relations with the OIC. The delegation also met with the President of the Chinese Islamic Association (CIA).

Beside the OIC, several agencies within the United Nations such as the Office of the Commissioner for Human Rights, UN High Commission for Refugees (UNHCR), UN Development Program (UNDP), UN Committee on the Elimination of Racial Discrimination (UNCERD) and the UN Independent Expert (UNIE) on Minority Issues have also been monitoring human rights conditions in Xinjiang.

The UN has also organised several fact-finding missions in the province to better understand the situation. In 2005, Manfred Nowak, the UN Special Rapporteur on Torture, observed that torture was still widespread throughout the Chinese penal system, despite Beijing's claims that it outlawed torture in $1996 .{ }^{48}$ In the report, Nowak appealed to China to reform its method of interrogation and its handling of detainees. The said report was highly damaging for China what more embarrassing for Beijing.

After the July 2009 riots, Nowak made similar remarks about Uyghur detainees being subjected to severe torture. He appealed 
to China to treat "the detainees in accordance with international standards, to accord the detainees due process." ${ }^{49}$ However, China refuted Nowark's claims and urged the UN not to interfere in China's penal system - a clear indication of denial.

The UN High Commissioner for Human Rights between 2008 and 2014, Navi Pillay, also expressed her concern over the large number of casualties during the July $2009^{50}$ and called on the Uyghur leaders as well as Chinese government to prevent further violence. She also urged China to provide proper treatment for political detainees as well as conduct a transparent and independent investigation into the causes of the riots. On this, Pillay stated that, "the right of demonstrators to exercise freedom of expression in a peaceful manner must be maintained. We fully recognise that the authorities have an essential duty to maintain public order. However, it is vital that authorities only resort to lethal force when it is strictly unavoidable in order to protect life." ${ }^{51}$ As usual, the reactions from Beijing were the same when it refuted Pillay's statements and called upon the UNHCHR not to interfere in China's domestic affairs.

On a similar note, the UNCERD urged China to observe human rights norms in Xinjiang, especially after the July 2009 riots. The UNCERD called on Beijing to guarantee humane treatment and fair trials for those held over the riots. Similarly, Gay J. McDougall, an UN Independent Expert called upon Beijing to allow a comprehensive and independent assessment of the ethnic tensions between the Hans and Uyghurs which had resulted in the outbreak of violence. She also requested permission to make an official visit to the province in her capacity as an Independent Expert on minority issues but was turned down by the Chinese government. ${ }^{52}$

It is interesting to note that the UN also acts as a platform for several Uyghur transnational advocacy groups to voice their plight. For example, during the 15th Session of the UN Human Rights Council (UNHRC) in Geneva from 13 September to 1 October 2010, the Society for Threatened Peoples, International Society for Human Rights and International Education Development, Inc. raised the issue of poor human rights conditions in Xinjiang. In turn, the Chinese delegation claimed that it was a domestic issue and that the UNHRC should not interfere in the country's domestic affairs. However, 
delegates from the U.S. and United Kingdom defended the rights of these groups to speak.

\section{THE UNITED STATES AND TURKEY}

Of all the Islamic countries around the world, Turkey has been one of the most forth-coming in raising the issue of poor human rights conditions in Xinjiang. In fact, Turkish Prime Minister, Tayyip Erdogan, even described Chinese human rights violations against the Uyghurs as an "atrocity" 53 , albeit diplomatic protests from Beijing. In 2009, when Turkey was non-permanent member of the United Nation's Security Council (UNSC), it did make an attempt to bring the Xinjiang issue to the attention of the UNSC, although China protested on grounds that it was a domestic affair. ${ }^{54}$

There were even street demonstrations in Turkey when the Turkish protested in front of the Chinese diplomatic missions in Ankara and Istanbul. Some of them even burned the Chinese flag and called on the Turkish people to boycott Chinese products. ${ }^{55}$ Turkey's concern over the condition in Xinjiang is motivated by its strong ethnic and cultural bonds with the Turkic speaking Uyghurs. Turkey's President, Abdullah Gul, urged that: "I hope the Chinese administration will assess all of these happenings (riots and outbreak of violence in Xinjiang) in an open, objective and transparent way." ${ }^{956}$

The U.S. has also consistently expressed its concern about the poor human rights conditions in Xinjiang and has been actively campaigning for the plight of the Uyghurs since the 1990s. The U.S. State Department has released numerous reports on human rights conditions in Xinjiang, which Beijing has been categorically denying.

Since the 1990s, American presidents have made a point to meet several Uyghur leaders in Washington D.C. as part of the U.S. effort to demonstrate its solidarity with the Uyghur community. For example, both President Bill Clinton and President George W. Bush invited Uyghur leaders to the White House. Although the meetings triggered diplomatic protests from the Chinese government, Washington wanted to signal that the U.S. is concerned about the plight of the Uyghurs and it may consider imposing sanctions against China if the condition deteriorates. 
The U.S. State Department has consistently condemned discrimination and human rights abuses in Xinjiang. ${ }^{57}$ For example, the State Department's 2008 Human Rights Report noted an increase in harsh repression of peaceful dissent and further restrictions imposed on cultural and religious practices among the Uyghurs by Beijing. ${ }^{58}$ The report also condemned selective persecution by the Chinese authorities against Alim Abdureyim and Ablikim Abdureyim (both sons of Rebiya Kadeer) and Mehbube Ablesh, an Uyghur writer and poet who was critical of Beijing. ${ }^{59}$ On 17 September 2007, the U.S. House of Representatives passed House Resolution 497 by voice vote which demanded that the Chinese government release the children of Rebiya Kadeer and Huseyin Celil, a Canadian citizen.

In the aftermath of the July 2009 riots, the State Department again expressed concern over human rights conditions in Xinjiang. It called on Beijing to observe restraint and urged transparency during the trials of those detained. On this, the State Department noted that "the US will continue to urge China to handle their detention and judicial processes in a more transparent manner." ${ }^{90}$ Similarly, the U.S. Secretary of State, Hilary Clinton, called on the Chinese government to ensure the preservation of human rights and freedom of worship among the minorities during her official visit to Beijing in December 2009. ${ }^{61}$

\section{CHINA'S REACTION}

China has adopted several counter-attack strategies in response to its critics. These strategies include rhetorical rejection of human rights interference and selective use of hard line tactics, combined with tactical concessions. To begin with, China has never questioned the validity of international human rights norms but hold that there should be no interference in its domestic affairs. One of the counter-attack strategies is to note that like-minded states such as the U.S. have committed even more violations of human rights, such as slavery. China also alleges that states which criticise its human rights policies in Xinjiang have double standards and that there are other countries with worse human rights conditions which are simply ignored. According to China, this double standard is part of an attempt by the capitalist states to prevent China from adopting a political system of its own choice. ${ }^{62}$ 
In addition and like most norm-violating states, China too often uses sovereignty as a shield to ward-off external criticism and pressure - evident in Chinese official propaganda. It claims that foreigners who criticise its human rights conditions are interfering in China's domestic affairs. According to China, many so called 'violations' of human rights in Xinjiang are not violations at all because foreign observers such as $\mathrm{AI}$ and IHRC do not understand the 'actual' situation in the province.

Furthermore, China argues that cultural standards in China and those in the rest of the world are different and as such foreigners cannot impose their understanding of human rights upon China. It considers the attempts of foreigners to impose their ideas of human rights an act of 'cultural imperialism'. Moreover, China also argues that human rights conditions in the developed states are not perfect, hence, they have no moral authority to judge or criticise China. On this, former Vice-Premier, Zhu Rongji stated that "I cannot see those countries who are promoting human rights have better record than ours." 63

Another strategy is to discredit the Uyghur solidarity groups by claiming that they advocate terror and violence in order to achieve their aims. China has raised this as an issue of national security and accused most of the Uyghur solidarity groups of being terrorists. The Chinese government have alleged that the attacks during the Olympics 2008 Games were planned by the Uyghur separatists. According to Amy Reger ${ }^{64}$, the CCP officials such as Wang Lequan and Nur Bekri have attempted to link human rights organisations with alleged terrorist groups in order to discredit their human rights efforts.

Reger adds that the Chinese government has also resorted to character assassination with respect to Uyghur activists like Rebiya Kadeer in an attempt to blame her and discredit her human rights' advocacy. In September 2009, Nur Bekri alleged that the WUC was an organisation that promoted violence although the WUC publicly denied its involvement in the July 2009 riots. ${ }^{65}$ Therefore, China justifies its harsh policies, such as the 'Strike Hard' policy', as necessary in order to defend its territorial integrity against the Uyghur separatist movement.

Although China has adopted a defensive approach in handling international criticism, it has also published several White Papers on human rights. These are significant as they are a sign of China's willingness to respond to international concerns as well as a part of the 
Chinese propaganda purporting to provide some form of explanation to the international community. On this, former Premier Li Peng states that: "We believe that the human rights and fundamental freedom of all mankind should be respected everywhere. China agrees that questions concerning human rights should be the subject of normal international discussion. ${ }^{\prime 66}$

At the international and regional level, China has dissuaded Central Asian states such as Uzbekistan and Kazakhstan who are sympathetic to the Uyghurs. China, through the Shanghai Cooperation Organisation (SCO), has pressured member states not to offer any assistance to Uyghur dissidents and political activists. For example, China was able to influence the Turkish government to reject the visa application of Rebiya Kadeer for her to attend the NED Conference which was held in Istanbul in $2006 .{ }^{67}$ It must be noted that the economic and diplomatic threats levelled by China on a number of states for refraining from assisting the Uyghurs have been enough to discourage states from supporting the Uyghurs.

Moreover, Western governments do not share a common and united stand over human rights in China. Their relations with China are driven by economic and security issues rather than human rights issues. China has also made itself very clear that any 'foreign interference' in its domestic politics would jeopardise its external relations. For example, during the European Union's Human Rights Dialogue with China on 8 February 1999, China's Vice Minister of Foreign Affairs, Wang Guangya, reiterated that "any country which wishes to resume the Geneva scenario would certainly do damage not only to the bilateral relations but also to the possibility of continuing the human rights dialogue." 68

\section{CONCLUSION}

This article has highlighted the work of TANs in putting the Xinjiang human rights issue on the international agenda and pressuring the Chinese government to promote better human rights in the province. The article begins by demonstrating the situation in Xinjiang since annexed the province in 1949. This article also highlights the implementation of the 'Strike Hard' policy, which can be considered the first phase, or repression phase of the spiral model. Religious 
gatherings were strictly monitored and freedom of speech and movement were denied. The security forces intensified arrests, torture and extra judicial killings in the province. Local political groups were suppressed and unable to pressure the Chinese government effectively. However, after the 1997 Yining crackdown and the arrest of Rebiya Kadeer in 1999, the Uyghurs launched the first of many 'boomerang throws' against China. They captured international media attention and increased international pressure on Beijing to improve the human rights conditions in Xinjiang. In addition, the Uyghur diaspora raised its concern about human rights violations in order to gain international support. Pressure came not only from the Uyghurs, but from nonUyghur communities and organisations as well.

Although this did not dramatically change human rights conditions in Xinjiang, it nonetheless led to the formation of a transnational advocacy network and the compilation of information on violations in East Turkestan. It also enabled the international community to lobby the Chinese government to respect international norms. Transnational advocacy groups, international organizations and like-minded states such as AI, the UN and U.S. began expressing their concern about the human rights situation in Xinjiang openly. This subsequently moved the issue from the first phase of the model to the second phase of the model, namely denial. In this phase and apart from issuing denials, Beijing also began using sovereignty and national integrity as a shield to ward-off international criticism and pressure. China has vehemently denied having violated any international human rights norms and the issue tantamount interfering in its domestic affairs. Uyghurs supportive of international criticism were labelled as traitors. It also made use of the September 11 attacks and the global war on terror to intensify its military crackdown on the Uyghur separatism. China also alleges that human rights advocacy groups such as AI and HRIC were trying to discredit the Chinese government. In response to political resistance, the Chinese government began dealing with the Uyghur nationalists, which led to backlashes in 2008 and then the July 2009 riots. In the aftermath of the riots, Chinese forces began cracking down on supporters of the Uyghur separatist movement, with increasing reports of arbitrary arrests, torture and killings. Once again the transnational network was activated and mobilised after the crackdown following the July 2009 riots. 
It is clear evident that the spiral model is useful in explaining the role of external factors in influencing human rights conditions in Xinjiang over the years. It has also been demonstrated that the various phases of the model might differ when applied to a specific area. Unfortunately, in the case of Xinjiang, it is yet to move moved beyond the third phase. There are several factors that have contributed to this stagnation. One major reason is due to backlash in Xinjiang where the human rights condition has worsened such that it has regressed back to the first phase - repression.

There are several reasons for the reversal. Firstly, the existence of an armed resistance, which Risse and Sikkink identify as a 'blocking factor' to moving forward in the spiral model. The emergence of Uyghur separatism justifies the greater presence of the Chinese military for reasons of national security and thus the backlash. This has been continued crackdowns and human rights violations against civilians, who the government often claim are 'terrorists'. In addition, the Uyghur opposition groups are fragmented and far from united. A number of domestic groups in Xinjiang have called for the establishment of a theocratic Islamic republic whereas some favour secularism. All the same, while some continue to work for improvement in human rights conditions in the province, others are however demanding outright secession from China. The latter has resulted in some states especially Turkey to reconsider its policy of supporting the Uyghurs as such demands could have a spiralling effect in the former itself.

Likewise, it is evident that China's rise as a major power has had a bearing on the issue as well. Whilst frequently irritated with reports of human rights violations, China has simply taken the position of not succumbing external pressure thus raising the issue of leverage over China. External criticism and pressure too has, at the best, produced mixed results. For example, without the external pressure exerted by the US, Rebiya Kadeer would not have been released in March 2015. But all the same, the backlash against Uyghur demands for separatism continues.

\section{NOTES}

1 Abdul Rashid Moten and El-Fatih A. Abdel Salam, Glossary of Political Science Terms: Islamic and Western, Singapore: Thomson Asia, 2005, p. 65. 
2 Ibid., p. 65.

3 Dawamat Tomur, Xinjiang-My Beloved Home, Beijing: China Today Press, 1993, p. 79.

4 Xinjiang Statistical Yearbook, Beijing: Beijing Information Press, 2005, p. 56.

5 Michael Dillon, Xinjiang-China's Muslim far Northwest, London: RoutledgeCurzon, 2004. See also, Frederick Starr (ed.), Xinjiang: China's Muslim Borderland, London: M. E. Sharp, 2004.

6 Thomas Risse and Kathryn Sikkink, "The socialization of international human rights norms into domestic practices: introduction," in Thomas Risse, Stephen C. Ropp and Kathryn Sikkink (eds.), The Power of Human Rights: International Norms and Domestic Change, Cambridge: Cambridge University Press, 1999, pp. 17-19.

7 Ibid., p. 22.

8 Ibid., p. 24

9 June Teufel Dreyer, China's Forty Millions: Minority Nationalities and National Integration in the People's Republic of China, Cambridge, MA: Harvard University Press, 1976, p. 104.

10 Donald McMillen, Chinese Communist Power and Policy in Xinjiang, Boulder, CO: Westview Press, 1979, p. 44.

11 Ibid., p. 68.

12 Zhu Peimin, Research on Xinjiang's $20^{\text {th }}$-Century History, Urumchi: Xinjiang Renmen Chubanshe, 2000, p. 73.

13 Ibid.

14 Ibid.

15 George, Moseley, A Sino-Soviet Cultural Frontier: the Ili Kazakh Autonomous Chou, Cambridge, MA: East Asian Research Center, Harvard University, 1966, pp. 105-106.

16 Sadri Roostam, "The Islamic Republic of Eastern Turkestan: a commemorative review," Journal Institute of Muslim Minority Affairs, No. 2, July 1984, pp. 294-319.

17 James A. Millward, Eurasia at Crossroads: A History of Xinjiang, Columbia: Columbia University Press, 2006, p. 270.

18 McMillen, Chinese Communist Power and Policy in Xinjiang, p. 298 19 Ibid.

20 Millward, Eurasia at Crossroads, p. 275. Information regarding the desecration of mosques were verified by Uyghurs and Huis during my 
interviews in Xinjiang in July 2011. They confirmed that the desecrations had happened and many cases were not reported.

21 Ibid.

22 Millward, Eurasia at Crossroads, p. 310.

23 Thomas K. Kostrzewa, "Separatist Nationalism in Xinjiang," Ph.D. Thesis, Notre Dame, IN: Notre Dame University, 1996, pp. 243-246.

24 Ibid

25 Xinjiang Ribao, pp. 72-78

26 Ibid.

27 Millward, Eurasia at Crossroads, p. 344.

28 Daniel Southerland is Vice President of Programming/Executive Editor, Radio Free Asia in Washington DC.

29 Amnesty International, People's Republic of China: Gross Violation of Human Rights in the Xinjiang Uighur Autonomous Region, London: amnesty International, April 1999, p. 8.

30 Ibid.

31 Yanda is the abbreviation of yanli daji yanzhong xingshi fanzui huodong or 'Campaign to strike severely at serious criminal offences.'

32 "Chinese Communist Party Document \#7," <http://caccp.freedomsherald. org/conf/doc7.html>

33 Risse and Sikkinik, "The socialization of international human rights norms into domestic practices," pp. 19-38.

34 Uyghur American Association, <http://www.uyghuramerican.org// articles/1842/1/Media-Advisory-UAA-Freedom-Torch>

35 Ibid.

36 Uyghur American Association, <http://www.uyghuramerican.org// aricles/1191/1/Rebiya-Kadeer-addresses $>$

37 Uyghur American Association, <http://www.uyghuramerican.org// aricles/3995/1/Obama-should-reiterate-US-concern-over>

38 "Rabiya Kadeer meets with President Bush," 30 July 2008, The Uyghur American Association, <https://uyghuramerican.org/article/rebiya-kadeermeets-president-bush-white-house.html>

39 Ibid.

40 "Rebiya Kadeer addresses PRC trafficking of Uyghur women and girls at Congressional briefing," 1 November 2007, The Uyghur American Association, <http://uyghuramerican.org/article/rebiya-kadeer-addressesprc-trafficking-uyghur-women-and-girls-congressional-briefing.html> 
41 "About UAA," The Uyghur American Association, <http:// uyghuramerican.org/about_uaa>

42 "Ms Rebiya Kadeer attends reception in honour of former Czech President Vaclav Havel," The Uyghur American Association, 21 February 2007, <https://uyghuramerican.org/article/ms-rebiya-kadeer-attendsreception-honor-former-czech-president-vaclav-havel.html>

43 Kyoko Hasegawa, "Uyghur leaders urge Japan to press China on rights, Agence France-Presse, 20 October 2009, <https://uyghuramerican.org/ article/uighur-leader-urges-japan-press-china-rights.html>

44 David Montgomery, "The Mother of the Uighur Movement," The Washington Post, 9 July 2009, <http://www.washingtonpost.com/wp-dyn/ cpntent/article/2009/07/08/AR200907080414>

45 People's Republic of China: Gross Violation of Human Rights in the Xinjiang Uyghur Autonomous Region, London: Amnesty International, 21 April 1999.

46 The Repressive Framework of Religious Regulation in Xinjiang, China Human Rights Forum, No. 2, 2005, New York: Human Rights in China, 2005.

47 "Address 'Root Cause' of Problem in Xinjiang OIC to China," Outlookindia.com, 9 July 2009, <http://wires.outlookindia.com/items. asp $\mathrm{a}$ artid $=662455>$

48 "Chinese embassy spokesman respond to international critics," Uyghur American Association, <http://www.uyghuramerican.org//articles/1317/1/ Chinese-embassy-spokesman-respond-to-international-critics>

49 "UN Rights Expert Seek Probe in China's Xinjiang Region," Z News, 22 December 2009, <http://zeenews.india.com/news/world/un-rights-expertseek-probe-in-chinas-xinjiang-region_589603.html>

50 “UN urges 'humane treatment' for Tibet, Xinjiang detainees," Sino Daily, 28 August 2009, <http://www.sinodaily.com/2006/090828133804.0edtzlhl. html>

51 "Human Rights Chief urges Leaders in China to Prevent Violence in Xinjiang," UN News, <http://www.unmultimedia.org/radio/english/ detail/77732.html>

52 "UN Minorities Expert Calls on China to Grant her Access to Assess Ethnic Tensions and Violence in Xinjiang Uyghur Region," Geneva: Office of the High Commissioner for Human Rights, 22 December 2009, <http:// www.uhrp.org/articles/3327/1/> 
53 “Turkish PM ups Rhetoric over Violence in Xinjiang," Hurriyet, 7 July 2009, <http://www.hurriyet.com.tr/english/domestic/12048159.asp>

54 Ibid.

55 "OIC Cites Economic Discrepancy as Reason for Xinjiang Violence," Today's Zaman, 24 August 2009, <http://www.todayszaman.com/diplomacy_ oic-cites-economic-discrepancy-as-reason-for-xinjiang-violence_184891. html>

56 "Turkish PM ups Rhetoric over Violence in Xinjiang."

57 Kara Miriam Wortman and Kerry Dumbaugh, China's Xinjiang-Uighur Autonomous Region: Developments and U.S. Interests, Report RS20476, Washington DC: Congressional Research Service, 2007, p. 5.

58 US State Department 2008 Human Rights Report, Washington DC: State Department, 25 February 2009, <http://www.state.gov/j/drl/rls/hrrpt/2008/ eap/119037.htm>

59 Ibid.

60 "US seeks China Transparency in Xinjiang Trials," The Bangkok Post, $<$ http://www.bangkokpost.com/news/asia/166826/>

${ }_{61}$ "US Secretary of State calls for Human Rights in Tibet and East Turkistan," The Tibet Post, 15 December 2009, <http://www.thetibetpost. $\mathrm{com} /$ news/international/537-us-secretary-of-state-calls-for-human-rightsin-tibet-and-eastern-turkistan>

62 Andrew J. Nathan, "Human Rights in Chinese Foreign Policy," The China Quarterly, No. 139, September 1994, p. 641.

63 Ibid.

${ }^{64}$ Amy Reger is a Researcher at the Uyghur Human Rights Project (UHRP).

65 Human Rights in Xinjiang: Recent Developments, p. 4.

66 Nathan, "Human Rights in Chinese Foreign Policy," p. 641.

${ }_{67}$ Human Rights in Xinjiang: Recent Developments, p. 9.

68 Amnesty International, "Open Letter from Amnesty International to EU Government on the Eve of EU-China Human Rights Dialogue," TG ASA 17/99.01, London: Amnesty International, 4 February 1999, <https://www. amnesty.org/en/documents/ASA17/008/1999/en/> 